\title{
Multidisciplinary Perspectives on Islamic higher Education Curriculum Orientation in Independent Campus Policy
}

\author{
Ahmadi Ahmadi \\ Institut Agama Islam Negeri Ponorogo, Ponorogo, Indonesia \\ ahmadi@iainponorogo.ac.id \\ Basuki \\ Institut Agama Islam Negeri Ponorogo, Ponorogo,Indonesia \\ basuki@iainponorogo.ac.id \\ Wirawan Fadly \\ Institut Agama Islam Negeri Ponorogo, Ponorogo,Indonesia \\ wira1fadly@iainponorogo.ac.id \\ Muhammad Thohir \\ UIN Sunan Ampel Surabaya,Surabaya,Indonesia \\ muhammadthohir@uinsby.ac.id \\ Samsul Ma'arif \\ UIN Sunan Ampel Surabaya,Surabaya, Indonesia \\ Samsul_jombang@yahoo.com
}

\begin{abstract}
Curriculum has strategic values in the era of independent campus. This research aims to construct a curriculum based multiple perspectives tends to learners' preference and diversity in Islamic Higher Education. It's a mixmethod research. Qualitative methods, using naturalistic design with interactive models, while quantitative methods with cross-sectional surveys to determine the level of stakeholder's understandings and the result of it. The result found that multiple dimensions leads to an eternal-essential closed to the Oneness of God, creativity, capability. The other one refers to instrument; model,
\end{abstract}


knowledge, organization, sequence, need analysis, purpose, value, and stakeholder. Furthermore, the appropriate one tends to an essential-humanistic technologies curriculum in fulfilling for independent campus recognition.

Keywords: Values, Curriculum, Orientation, Domain

\begin{abstract}
Abstrak
Kurikulum memiliki nilai strategis di era kampus merdeka. Penelitian ini bertujuan untuk mengkonstruk kurikulum dari berbagai perspektif sebagai tuntutan diversifikasi preferensi pembelajar perguruan tinggi Islam. Metode penelitian yang dilakukan adalah mix-method. Secara kualitatif dilakukan melalui metode naturalistik dengan model interaktif, sedangkan kuantitatif dengan metode survei cross sectional untuk mengetahui tingkat perspektif stakeholder, serta dampak perubahan yang terjadi. Hasil penelitian menunjukkan dimensi eternal-esensial yakni memenhi kebutuhan akan esesi yang mendasar Ke-Tuhanan, kreatifitas, kapabilitas dan dimensi instrumental; model, pengetahuan, organisasi, sequensi, analisis kebutuhan, purposes, nilai, dan stakeholder. Trend ke depan, kurikulum sebaiknya diarahkan ke esensialhumanistik teknologis untuk mengisi rekognisi kampus merdeka.
\end{abstract}

Kata Kunci: Nilai, Kurikulum, Orientasi, Dimensi

\title{
A. Introduction
}

Both Independent campus and learning is popular policy recently introduced by Nadhim Makarim, Indonesia Education and Culture Minister. It drives to stakeholder to understand anymore and intensify his paradigm. One of reason is if there are some obstacles in Islamic higher education generally faces challenges related to the quality of education, ranging from input to processes of outcomes. Those cases happened because of disequilibrium among social, economics, politics in society, and inequity injustice, violence, riots, and corruption that have spread to all sectors in society (Cheng et al., 2011; Julaiha, 2014; Viennot \& Décamp, 2016). The quality of today's education is a very important need related to human life (Shapiro, 2003; Wolf, 2007).

The future of a nation is very dependent on the nation's education. If the education of a nation can produce high quality of human beings are born, automatically the citizenship's welfare will be advanced and peaceful. Education can make the process of maturing the quality of learners to be developed by freeing them from ignorance, disability, helplessness, unrighteousness, and bad morals and faith (Mulyasana, 2011; Topcu, 2010; Yahaya et al., 
2016). By education, the quality of Godhead can be improved (Miller \& Seller, 1985). Obedience to the divine principle must live in Him, and the free representation of this principle in his life. Education, in instruction, should lead man to see and know the divine, spiritual, and eternal principle which animates nature constitutes the essence of nature and is permanently manifested in nature. Miller and Seller, education can guide people to know the values of God, spiritual, and transcendent bases that surround permanently in the universe. Thus, the educational position in human life is very enlightening, which can improve the quality of one's degree. The awareness of God's values and the environment is increasingly meaningful, sharp, and clear that can encourage his gratefulness (Mansour, 2015). As to the national educational goals introduced in the Act of the Republic of Indonesia on National Education System Number 20, year 2003 in the chapter 3. The aim of education in Indonesia is to develop learners' potentials so that they become persons imbued with human values who are faithful and pious to one and only God; who possess morals and noble character; who are healthy, knowledgeable, competent, creative, independent; and as citizens, are democratic and responsible.

Islam has a very clear, whole and comprehensive concept of human resource development. Mulyasana said that there are eight functions of education; (i) education fosters awareness of life and the cycle of life processes, (ii) education helps humans adjust to the demands of change and something new, (iii) education helps to release people from ignorance, poverty, and backwardness, (iv) education helps human to perform the process of identity formation, (v) education helps to break the gap of life in the midst of the complexity of change, (vi) education helps humans to understand the meaning and the nature of life, (vii) education helps humans to mature the process of self-qualities towards the formation of superior personality and the achievement of the point of self-perfection, (viii) education helps nurture morality (Mulyasana, 2011; Sanaky, 2008; Shulhan, 2017).

Curriculum orientations such as Alismail \& McGuire (2015), Tutkun (2010), Sopiah (2020), Musyafiudin \& Ahmadi (2020), Barni \& Mahdany (2017), Ali, (2018), Zaman (2019), Nugroho (2017), Farihah \& Nurani (2017), dan Safitri (2020) is one of the important tools in achieving educational success. Without a good and proper curriculum, it will be difficult to achieve the goals and objectives of education aspired, This premise is in line with Sopiah's finding that the curriculum has a central position, even during the distance learning period, especially in strengthening character education values. More deeply from the findings of Ahmadi et al, that character is built by internalizing attitudes and values, both through exemplary habituation, intervention, and reinforcement. Meanwhile, Muslih has seen an 
orientation towards strengthening the construction of Qur'anic values based on Abdullah Saeed's contextual interpretation, so Fahri Ali measures it in terms of the extent to which these values are useful in everyday life. For that, Badrus Zaman et al underline it as an obligation between humans. so the curriculum has a central position in the entire educational process. Curriculum model is a scientific activity that aims at students so that they surely acquire the knowledge based on the construction of curriculum design principles as in general

Even though Nugroho (2017), Farihah \& Nurani (2017), dan Safitri, 2020) has studied the internalization of values, but the studies above still leave issues that have not been touched, namely how curriculum designers must pay attention to the hierarchy of values contained in the goals of national education. By relying on the premise of Thohir et al. (2020) that the perspective can affect results and performance, then the study aimed to construct a curriculum from various perspectives based on the order of the values of faith, piety, and noble character, as a demand for diversifying the preferences of Islamic higher education students.

By using a mixed method research (MMR) approach, qualitatively, it was done through naturalistic methods with interactive models, while quantitatively with cross sectional survey methods to determine the level of stakeholder perspectives, as well as the impact of changes that occur. The object of the study is the value model used at Magister Program at IAIN Ponorogo which offers new knowledge about how the curriculum is built on the basis of corporate values, totally muslim and truly intellect, which has unique principles.

\section{B. Discussion}

Curriculum should be more dominant in obtaining real intellectual core values (observing, responding, arguing, conducting research and academic creativity). Although it is dominant in the intellectual realm, the implementation is based on Islamic theological values, either.

\section{Philosophy}

The courses at Magister IAIN Ponorogo are classified into four models. First is an academic subject curriculum model. This is a series of concepts or materials that have been considered to be solidly systemized by Magister IAIN Ponorogo, so that the courses that are deemed necessary must be submitted to students. It's assumed that students are followers from past scientists and researchers who leave various disciplines that must be submitted to the next generation. The students who fulfill the subjects are possible to become academic and 
idealistic students. The courses included in the academic subject group are; Reading on Arabic and English Text, business ethics, and ZIS-waqaf jurisprudence.

Second, humanist curriculum one; this is a subject that views students as totally human being, so that students must be guided from various aspects including monotheism, worship, social aspects, endeavors, resignation, observation, response, argumentative abilities, research abilities, creativity, and productivity in order to become a perfect human being. The subjects contained in this model are tafsir and hadith studies. The course sets the foundation for various other courses marketed in the following semester, so that understanding and discussion become complete and comprehensive.

Third, technological curriculum one, which is a curriculum that looks at changes in behaviour, even the behavior of IAIN Ponorogo graduate students can be measured scientifically. The values of scientific thinking is starting from the stages of understanding, comprehending, applying, analysis, synthesizing, evaluating, and creating are the key to the meaningfulness and success of the students and lecturers of Magister. The courses that are grouped in this model are the philosophy of science, Islamic perspectives, research methods, micro-macroeconomics, sociolinguistic, semantics, facilities-infrastructure management, education supervisions, educator-education staff, supervisory oversight, and psychology of family.

Fourth, social reconstruction curriculum one, Magister intends that students are classified as great human beings who are able to solve various problems that occur in the community that are in accordance with the discipline of their respective study programs. The learning process is more inclined to use a problem-based curriculum. The courses contained in this model are economic in Islam, sharia banking law, economic-sharia dispute settlement, sharia financial institutions, research methodology, constituent law and unions in Islam, strategic management, TQM, HRM, management of education curriculum Islam, the philosophy of Islamic education, Islamic education policy studies, management of Islamic education institutions, proposal seminars, and thesis.

\section{Knowledge}

Knowledge is a system (sunnatullah scattered on the earth as verses of the greatness of Allah Almighty) that must be sought and understood by all human kinds. The struggle to seek knowledge is ascertained on the road to the heaven of Allah Almighty, so students and lecturers are encouraged to always gain knowledge because it is very important in the development of Magister IAIN Ponorogo curriculum. The stakeholder expects students to 
gain various knowledges. First is a factual knowledge; knowledge that is at the level of real facts. The truth that is in accordance with the indicators that are happening, Time space and place contributes to the reading of the truth. The subjects given are grouped into factual knowledge are Arabic and English Reading Text, language and English language and also cannot be accessed in other subjects.

Second is a conceptual one. Sharia Economics Program and Islamic Education Management programs provide conceptual knowledge to students Courses that are marketed in this program are predicted to have conceptual rich knowledge. This is a provision for running as an intellectual Muslim. The subjects that must be obtained by the students are a study in Al-Qur'an, study in Hadith, fiqh proposals, philosophical science, sharia banking law, ZIS fiqh and endowments, and Islamic education philosophy.

Third is a procedural one; it's much about the stages that must be passed to achieve scientific knowledge. Those are more dominant in achieving quality intellectual values. The courses given to students are Islamic religious law, research methods both sharia economics and education management, education statistics, implementation of sharia education, contract law and unions in Islam, education and Islamic education, educators and education staff, school management and supervision.

Fourth is meta-cognition one, which is multi-functional knowledge that can provide more value and sustainable. The purpose is that the achievement of high-level thinking is the ability to parse, draw conclusions, assess, create and market. The courses grouped into this knowledge are the Islamic worldview, micro and macroeconomic, sharia economic, sharia institutional finance, sharia economic business ethics, management strategy, TQM, Islamic education HRM, curriculum management, facility management infrastructure, study of education policy in Indonesia, Islamic education, , seminar proposals, and literary thesis.

\section{Organization}

The curriculum organization is a basis and grouping of several courses offered by Magister with goals based on core values that can be given well. The purpose of this organization, students and lecturers must be equipped with high-level thinking skills as a provision for carrying out the duties as an intellectual Muslim.

In general, this is divided into three groups; (i) Subject Academics Curriculum. The courses in this group are subjects whose materials are so solid. The strategic values are expected from the subjects. Course subjects belongs to this group are a reading on Arabic and 
English Text, English and Arabic, methodology in Islamic Study, educational research methods and sharia economics, educational statistics, (ii), Separate Subject Curriculum. Intellectual values expected from this group are students who want to learn about various concepts and richly solid material and scientists. Scientists previously thought that students were constructed from various components, students' knowledge plans could also be separated. Those Subjects are proposals of jurisprudence, philosophy of science, micro-macroeconomics, sharia economic, sharia banking law, ES settlement, sharia financial institutions, Islamic research and education, ethics business in Islam, Fiqh and endowments, contract law and unions in Islam, management strategies, TQM, HRM in Islam, Islamic education curriculum management, infrastructure management, Islamic education policy studies in Indonesia, Islamic education, Islamic education and education, Islamic educators and education, schooling and supervision. (iii) Integrated Curriculum; this is a combination among aspects, should understood comprehensively together, so it's hoped that has impact to students and lecturers will be able to behave wisely and to take a policy in social, leadership, communication, management, occupation, education, and economic. Magister Program compiles an integrated curriculum with the aim of providing opportunities for students to communicate all the lectures material provided from the first semester to the third semester into one product that can unite all components. This is presented in this session are proposal seminars and thesis writing.

\section{Sequences}

The skill is the complexity of the curriculum material from the basic level to the highest level of complexity. Thinking skills, in general, are arranged in accordance with the hierarchy of skills achieved, as well as cognitivist theory, so the programming of courses is also adapted to cognitive theory. Magister curriculum can be explained as follows; (i) Basic Level, in the first semester various subjects have been presented as a basis for further study. All undergraduate courses are developed and analyzed based on basic courses. They are subjects; Study in Al-Qur'an, study in Hadith, English, Arabic, philosophy of science, MSI, strategy management, integrated quality management, and Islamic world views. Some of expected values are hierarch thinking of students and lecturers as well as theories about thinking skills that the ability to think has stages; understanding, comprehending, applying, analyzingsyntheing, evaluating, and creating. (ii) Complex level, which is a course that must be parsed from various perspectives of scientific disciplines so that clear correlation is established between the various disciplines, consequently students and lecturers are required to think metacognition. They are; micro-macro economics, law on sharia welfare, sharia economic 
dispute settlement, sharia financial institutions, sharia economic research methodology, business ethics in Islam, jurisprudence and endowments, contract law and unions in Islam, Islamic education HRM, Islamic education curriculum management, Islamic infrastructure management, Islamic education philosophy, Islamic education policy study in Indonesia, Islamic education institution management, supervision and evaluation of Islamic education, Islamic education and education staff, school and supervision. At last, (iii) Very complex level; Magister Image building has reliable abilities as stated in Magister vision and mission. The courses are a writing of thesis proposal and the results of the thesis research.

\section{Needs Analysis}

Curriculum planning is based on core at Magister IAIN Ponorogo is placed on various demands, stakeholder offered to the needs of both internal needs and demands for change outside IAIN Ponorogo. In this era of global change requires education managers to be sensitive to the desires of customers for education both internal customers; students, lecturers, between leaders and stakeholders, as well as externally include demands that take into national political changes in education, global economy, social, environment and diversification of education marketshare. Those demands are; (i) Universal one; courses are closely related to; reading on Arabic-English text and study in Islamic methods. (ii) Essential one; course are content of monotheism, worship, social, endeavor, and trust in accordance with the rules of Qur'an and Hadith. Besides that; values related with intellectual; observation, response, argumentative ability, research and scientific work productivity; Islamic world views, fiqh proposals, sharia banking law, business ethics in Islam, ZIS fiqh and endowments, contract law and unions in Islam, the philosophy of Islamic education.

\section{Purposes}

Each subject has an academic function for achievement the objectives of Magister IAIN Ponorogo curriculum. Structure of curriculum planning has a strong function and reason for each IAIN Ponorogo; (i) Analysis Function, the courses in this group can be used as a tool for analyzing problem facts, data, phenomena, variables, and various factors, so that the meaning can be accounted for in accordance with scientific principles. (ii) Materials one. The course is ascertained to be rich in the material in accordance with the needs of the study program with the aim of deepening and broadening the understanding of the discipline of each study programs. They are all subject closed related with developing mastering materials enrich several sciences, and (iii) Product one, proposals and thesis writing are final assignments in study at Magister IAIN. thesis product is a real product which is expected as a starting point for 
one alternative that can solve various solutions to various problems in community. Thesis is a transformative product of students and lecturers on intellectual values and also the values of a Muslim who must do as well as to others by providing the best product. Finally, it is based on four pillars of thought; Islamic theology, philosophical basis, theoretical basis, and policy foundation.

Curriculum policy is absolutely an important component construction in magister curriculum because of giving direction to all curriculum practices where education will go so far, and character values are essentials for this. Moreover, the curriculum has to be implemented in the era of new wave technology that can make most netizens lost their own basic characters. Magister IAIN Ponorogo has distinctive core values used as curriculum development.

The writers found that the domain of Totally Muslim and Truly Intellect motto referred to (i) Character; it refers good, true, utility based values in both of them, (ii) Status; it refers to values are meaningful for instrument to gain motto, whereas terminal has final status, so it cannot be enlarged anymore, (iii) Sources; it refers to human creature, and God as the One of God that has eternal all something in universe, (iv) Level; it tends to area of usage values both local or universal, ( $\mathrm{v}$ ) Orientation; it covers a transmission, transaction, and transformative orientation. Both lecturers and students have processed of facts, skills and values using them during involving to attach muslim, intellectualist, and transformers in the society.

\section{Level of student understanding on curriculum management}

In this study, a survey was conducted to see the level of understanding of graduate students towards the curriculum developed and understanding of core values. The following table describes the distribution of curriculum understanding.

Tabel 1. Level of Students' Understanding of Curriculum

\begin{tabular}{lc}
\hline Understanding Aspect & Score \\
\hline Curriculum knowledge & 3,0 \\
Organizational curriculum & 2,4 \\
Curriculum objectives & 2,9 \\
\hline
\end{tabular}

Based on the data, magister students have understood in aspects of curriculum knowledge have an average score of 3,0, in the aspect of understanding organizational curriculum it has an average score of 2,4 , in the aspect of understanding of curriculum 
objectives has an average score of 2,9. Through this data, it can be seen that graduate students in understanding the curriculum have an average score in the aspect of understanding knowledge, while the lowest average value in the aspect of understanding the curriculum organization. The aspects of understanding the curriculum organization and understanding the curriculum objectives in the category are quite good, while the aspects of knowledge about the curriculum are included in either category. For this reason, it can be seen that students are better able to understand the curriculum and understand the organization and objectives of the curriculum developed. This is related to the experience in curriculum development that they have understood during study. This can be realized from these two aspects that have a higher cognitive level than the aspect of knowledge about the curriculum.

Tabel 2. Level of Understanding about Core Value

\begin{tabular}{lc}
\hline Understanding About Core Value & Score \\
\hline Totally Muslim & 2,4 \\
Truly Intelectual & 3,0
\end{tabular}

Based on research data that has been collected, students have a level of understanding between core values in the totally Muslim aspect of 2,4 or the category of fair, the aspect of truly intellectual has a value of 2,8 in good category. Through these data, it can be stated that graduate students have a better understanding perspective on truly intellectuals than totally Muslims, although most students have an educational background at the undergraduate level, mostly from graduates of Islamic universities. This is thought to have occurred because the educational background of graduate students who were previously more emphasized on the aspect of knowledge, not on the aspect of internalizing Muslim values themselves, even though in education there is now a basis that underlies their general knowledge in the form of religious material that is minimally obtained in the subject matter in the semester early.

From the description data above, we can discuss anymore that in orientation should track several perspectives to cover what do learners' needs. Curriculum model should be a scientific activity that aims at students so that they surely acquire the knowledge based on the construction of curriculum design principles as in general (Musyafiudin \& Ahmadi, 2020; Barni \& Mahdany, 2017).

Curriculum must be sophisticated because of learners created by Allah Almighty in complexity, perfect, and unique creature. Beside, customer or learners are consist of whole human; mind, heart, and spirit (Kotler et al., 2014). There are ten variety social drives to supply learners' necessities should be considered to design a curriculum (Parker, 2017). 
The purpose of model is to find a better value for life for themselves, institutions, society, religion, nation and state (Musyafiudin \& Ahmadi, 2020; Barni \& Mahdany, 2017).

The below table indicated there are aspects and components found in curriculum orientation constructed at Magister IAIN Ponorogo;

Tabel 3. Domains of Multiple Perspectives Orientation

\begin{tabular}{|c|c|c|c|c|c|c|}
\hline \multirow{2}{*}{\multicolumn{2}{|c|}{ CORE VALUES }} & \multicolumn{5}{|c|}{ DOMAINS } \\
\hline & & \multirow{2}{*}{$\begin{array}{l}\text { CHARAC } \\
\text { TER } \\
\text { Good }\end{array}$} & \multirow{2}{*}{$\begin{array}{l}\text { STATUS } \\
\text { Terminal }\end{array}$} & \multirow{2}{*}{$\begin{array}{l}\text { SOURCES } \\
\text { God }\end{array}$} & \multirow{2}{*}{$\begin{array}{l}\text { LEVEL } \\
\text { Local }\end{array}$} & ORIENTATION \\
\hline \multirow[t]{5}{*}{ MUSLIM } & $\begin{array}{l}\text { Oneness of } \\
\text { God }\end{array}$ & & & & & Transmition \\
\hline & Worship & True & Terminal & God & Universal & Transformation \\
\hline & Social & $\begin{array}{l}\text { Good } \\
\text { Utility }\end{array}$ & Terminal & $\begin{array}{l}\text { God } \\
\text { Human }\end{array}$ & Universal & Transformation \\
\hline & Initiative & $\begin{array}{l}\text { True } \\
\text { Utility }\end{array}$ & $\begin{array}{l}\text { Instrume } \\
\text { nt }\end{array}$ & Human & Local & Transformation \\
\hline & Tawakkal & Good & Terminal & $\begin{array}{l}\text { Human } \\
\text { God }\end{array}$ & Universal & Transformation \\
\hline \multirow[t]{6}{*}{$\begin{array}{l}\text { INTELLEC } \\
\mathrm{T}\end{array}$} & $\begin{array}{l}\text { Observatio } \\
\mathrm{n}\end{array}$ & Good & $\begin{array}{l}\text { Instrume } \\
\text { nt }\end{array}$ & God-Human & Universal & Transmision \\
\hline & Responsive & True & $\begin{array}{l}\text { Instrume } \\
\text { nt }\end{array}$ & Human & Universal & Transactional \\
\hline & $\begin{array}{l}\text { Argumentio } \\
\mathrm{n}\end{array}$ & True & $\begin{array}{l}\text { Instrume } \\
\mathrm{nt}\end{array}$ & Human & Universal & Transactional \\
\hline & $\begin{array}{l}\text { Critical } \\
\text { Thinking }\end{array}$ & True & $\begin{array}{l}\text { Instrume } \\
\text { nt }\end{array}$ & Human & Universal & Transactional \\
\hline & Research & $\begin{array}{l}\text { Good- } \\
\text { Utility }\end{array}$ & $\begin{array}{l}\text { Instrume } \\
\text { nt }\end{array}$ & Human & Universal & Transformation \\
\hline & Creativity & $\begin{array}{l}\text { Good- } \\
\text { Utility }\end{array}$ & $\begin{array}{l}\text { Instrume } \\
\text { nt }\end{array}$ & Human & Universal & Transformation \\
\hline
\end{tabular}

The totally Muslim aspect is an attitude or knowledge that is not easily obtained instantly, so to associate, explore, appreciate verses in Qur'an requires fundamental and indepth knowledge that is not only limited to the material obtained in following some courses in an early semester (Abd-Allah, 1998). It is different from truly intellect, which almost requires the same aspects every semester. This factor is by humanistic learning theory which states that the learning process must return to the human potential itself by realizing the potential that exists in themselves (Chen \& Cowie, 2013; Campbell et al., 2014). So, it can be said that on a large scale students are superior in the truly intellectual aspect than truly Muslims because they 
have different potential between the two aspects where this potential could be influenced by educational background. A theory stated by John Dewey where knowledge and experience are very related in learning (Turkka et al., 2017; Hammo \& Saraireh, 2010; Slavin, 2019). However, aspects of understanding the organization of the curriculum and understanding of the curriculum have a lower value than aspects of knowledge.

The KKNI-oriented curriculum at PTKIN Postgraduate in East Java was implemented at different times. There was no specific and similar schedule in term of its implementation across the institution. Some lecturers did not have a sense of task, so that the regulation of the KKNI-orientation curriculum was carried out on their own initiative (Ahid \& Chamid, 2021). An integrative \& interconnected paradigm at UIN Sunan Kalijaga Yogyakarta is science concept that tries to reach, connect, bind among social, exact, Islamic knowledge, and humanities, so they will be meaningful each other. It seeks to combine religious scholarship with science and philosophy. It's popular spider web paradigm (Arbi, Imam Hanafi, Munzir Hitami, 2018; Yulanda, 2020: Fahmi \& Rohman, 2021). The other one, UIN Maliki Malang introduces philosophy of the three of knowledge. (Arbi, Munzir Hitami, 2018; Darwis \& Rantika, 2018).

The philosophy, in sequences of body of science, was found at IAIN Ponorogo has covered several domains; character, status, sources, level, and orientation. Besides, It is also consist of indicators of Muslim and Intellect; Oneness of God, worship, social, initiative, tawakkal, observation, responsive, argument, critical thinking, research, and creativity. It's concluded that the combinations of them are named the matrix of knowledge.

\section{Conclussion}

Islamic core values, in curriculum orientation, have been a fundamental aspect for constructing the outcome character. It refers to the Oneness of Allah, social activities, and effort to success. Besides that, developing an intellectual and analogical reasoning, those are competences to observe, responsive, argument, conduct research, and academic creativity. Internalization of them on curriculum orientation has embodied in the curriculum component. Those are developed by multiple orientation; cognition, instrument, knowledge, organization, model, paradigm, and philosophies. The outcomes will not only be able to behave range from lower to the higher order thinking skills but also become to be the real Muslim so far. Finally, the appropriate one tends to an essential-humanistic technologies curriculum orientation in fulfilling for independent campus recognition. 


\section{References}

Abd-Allah, S. (1998). Islamic Curriculum Development in Masjid Al-Qur'an's Full Time School. Religion and Education, 25(1-2), 77-86. https://doi.org/10.1080/15507394.1998.11000881.

Ahid, N., \& Chamid, N. (2021). Implementation of Indonesian National Qualification Framework Based Curriculum in Higher Islamic Education. Jurnal Pendidikan Islam, 7(1), 109-122. https://doi.org/10.15575/jpi.v7i1.12425

Ali, F. (2018). Incorporating Values of Moderate Islam for the 21st Century Learners in an English as a Foreign Language Class. Edukasia Islamika, 24. https://doi.org/10.28918/jei.v3i1.1676.

Alismail, H. A., \& McGuire, P. (2015). 21 St Century Standards and Curriculum: Current Research and Practice. Journal of Education and Practice, 6(6), 150-55.

Arbi, Imam Hanafi, Munzir Hitami, H. (2018). Model Pengembangan Paradigma Integrasi Ilmu Di Universitas Islam Negeri Sunan Kalijaga Yogyakarta Dan Universitas Islam Negeri Maulana Malik Ibrahim Malang. Profetika, Jurnal Studi Islam, 20(0274), 11-15.

Barni, M., \& Mahdany, D. (2017). Al Ghazali's Thoughts on Islamic Education Curriculum. Dinamika Ilmu, 17(2), 251-60.

Campbell, T., Zuwallack, R., Longhurst, M., Shelton, B. E., \& Wolf, P. G. (2014). An Examination of the Changes in Science Teaching Orientations and TechnologyEnhanced Tools for Student Learning in the Context of Professional Development. International Journal of Science Education, 36(11), 1815-48. https://doi.org/10.1080/09500693.2013.879622.

Chen, J., \& Cowie, B. (2013). Engaging Primary Students in Learning about New Zealand Birds: A Socially Relevant Context. International Journal of Science Education, 35(8), 1344-66. https://doi.org/10.1080/09500693.2012.763194.

Cheng, M. T., Annetta, L., Folta, E., \& Holmes, S. Y. (2011). Drugs and the Brain: Learning the Impact of Methamphetamine Abuse on the Brain through a Virtual Brain Exhibit in the Museum. International Journal of Science Education, 33(2), 299-319. https://doi.org/10.1080/09500693.2010.482571.

Darwis, M., \& Rantika, M. (2018). Konsep Integrasi Keilmuan dalam Perspektif Pemikiran Imam Suprayogo. Fitra, 4(1), 1-11.

Fahmi, I. R., \& Rohman, M. A. A. (2021). Non-Dikotomi Ilmu: Integrasi-Interkoneksi Dalam Pendidikan Islam. Al-MIKRAJ: Jurnal Studi Islam Dan Humaniora, 1 (2)(2), 49.

Farihah, I., \& Nurani, I. (2017). Internalisasi Nilai-Nilai Keislaman Dalam Skema Hidden Curriculum Di Mts Nurul Huda Medini Demak. Edukasia : Jurnal Penelitian Pendidikan 
Ahmadi Ahmadi, Basuki, Wirawan Fadly, Muhammad Thohir, Samsul Ma'arif

Islam, $\quad 12(1)$,

213-234.

http://journal.stainkudus.ac.id/index.php/Edukasia/article/view/2347

Hammo, B., \& Saraireh, B. (2010). Integrating ICT in Education: Impact on Teachers' Beliefs and Practices. In ICT Acceptance, Investment and Organization: Cultural Practices and Values in the Arab World (pp. 52-66). https://doi.org/10.4018/978-1-60690-0488.ch004.

Julaiha, S. (2014). Implementasi Pendidikan Karakter Dalam Pembelajaran. Dinamika Ilmu, $14(2), 226-39$.

Kotler, P., Kertjaya, H., \& Setiawan, I. (2014). Marketing 3.0. John Wiley \& Sons, Inc.

Mansour, N. (2015). Science Teachers' Views and Stereotypes of Religion, Scientists and Scientific Research: A Call for Scientist-Science Teacher Partnerships to Promote Inquiry-Based Learning. International Journal of Science Education, 37(11), 1767-94. https://doi.org/10.1080/09500693.2015.1049575.

Miller, J. P., \& Seller, W. (1985). Curriculum Perspectives and Practice. ERIC.

Mulyasana, D. (2011). Pendidikan Bermutu Dan Berdaya Saing. Remaja Rosdakarya.

Musyafiudin, M., \& Ahmadi, A. (2020). Enlighment Strategy Leads To A Quality Learning At Islamic School In 4.0 Era. Proceedings of the 5th International Conference on Education in Muslim Society, ICEMS 2019,30 September.

Nugroho, P. (2017). Internalisasi Nilai-Nilai Karakter Dan Kepribadian Mahasiswa Pendidikan Agama Islam Melalui Pendekatan Humanis-Religius. Edukasia: Jurnal Penelitian Pendidikan Islam, 12(2), 355. https://doi.org/10.21043/edukasia.v12i2.2491

Parker, L. (2017). Religious Environmental Education? The New School Curriculum in Indonesia. Environmental Education Research, 23(9), 1249-72. https://doi.org/10.1080/13504622.2016.1150425.

Safitri, E. (2020). Instilling the Value of Religious Pluralism as the Effort to Overcome the Religious Conflict. Edukasia: Jurnal Penelitian Pendidikan Islam, 15(1), 19. https://doi.org/10.21043/edukasia.v14i2.3897

Sanaky, H. A. H. (2008). Permasalahan Dan Penataan Pendidikan Islam Menuju Pendidikan $\begin{array}{llll}\text { Yang Bermutu. } & \text { El-Tarbawi, } & \text { 83-97. }\end{array}$ https://doi.org/10.20885/tarbawi.vol1.iss1.art7.

Shapiro, D. F. (2003). Facilitating Holistic Curriculum Development. Assessment and Evaluation in Higher Education, 28(4), 423-34. https://doi.org/10.1080/0260293032000066245.

Shulhan, M. (2017). Dialektika Gaya Kepemimpinan Transformatif Dan Madrasah Unggul Dalam Perspektif Kebijakan Daya Saing Pendidikan Bermutu. 
https://doi.org/10.21274/taalum.2017.5.2.79-108.

Slavin, R. E. (2019). Educational Psychology: Theory and Practice. Allyn and Bacon.

Sopiah, S. (2020). Reinforcing Character Education Values on Islamic Education in the Time of Distance Learning. Edukasia Islamika, December, 175-88. https://doi.org/10.28918/jei.v5i2.3189.

Thohir, M., Kurjum, M., \& Abdul Muhid UIN Sunan Ampel Surabaya, D. (2020). Design and Discourse of Modern Arabic E-Textbook. In LITERA: Jurnal Penelitian Bahasa, Sastra, dan Pengajarannya (Vol. 19, Issue 1). https://doi.org/https://doi.org/10.21831/ltr.v19i1.28901

Topcu, M. S. (2010). Development of Attitudes towards Socioscientific Issues Scale for Undergraduate Students. Evaluation and Research in Education, 23(1), 51-67. https://doi.org/10.1080/09500791003628187.

Turkka, J., Haatainen, O., \& Aksela, M. (2017). Integrating Art into Science Education: A Survey of Science Teachers' Practices. International Journal of Science Education, 39(10), 1403-19. https://doi.org/10.1080/09500693.2017.1333656.

Tutkun, Ö. F. (2010). The Philosophic Dimensions of Curriculum in the 21 St Century. Gazi Eğitim Fakültesi Dergisi, 30(3), 993-1016.

Viennot, L., \& Décamp, N. (2016). Conceptual and Critical Development in Student Teachers: First Steps towards an Integrated Comprehension of Osmosis. International Journal of Science Education, 38(14), 2197-2219. https://doi.org/10.1080/09500693.2016.1230793.

Wolf, P. (2007). A Model for Facilitating Curriculum Development in Higher Education. New Directions for Teaching and Learning, 112, 15-20. https://doi.org/10.1002/tl.294.

Yahaya, J. M., Nurulazam, A., \& Karpudewan, M. (2016). College Students' Attitudes towards Sexually Themed Science Content: A Socioscientific Issues Approach to Resolution. International Journal of Science Education, 38(7), 1174-96. https://doi.org/10.1080/09500693.2016.1174349.

Yulanda, A.-. (2020). Epistemologi Keilmuan Integratif-Interkonektif M. Amin Abdullah Dan Implementasinya Dalam Keilmuan Islam. TAJDID: Jurnal Ilmu Ushuluddin, 18(1), 79104. https://doi.org/10.30631/tjd.v18i1.87

Zaman, B. (2019). Moral Education of Children Streets In PPAP Seroja Surakarta. Edukasia Islamika, 18-32. https://doi.org/10.28918/jei.v4i1.2263. 
Ahmadi Ahmadi, Basuki, Wirawan Fadly, Muhammad Thohir, Samsul Ma'arif 